\title{
BARTOSZ PŁOTKA
}

Nicolaus Copernicus University in Toruń

ORCID ID: https://orcid.org/0000-0002-6385-2046

\section{A Report from $V^{\text {th }}$ International Asian Congress and the XIIth International Conference - The Direction of Asia, Diversity, Dialogue on the $100^{\text {th }}$ Anniversary of Poland's Independence and Azerbaijan Independence, Toruń, May 9-11, 2018}

\author{
Отчет c V Международного азиатского конгресса \\ и XII Международной конференции «Направление Азии, \\ разнообразие, диалог в связи со 100-летием независимости
}

Польши и независимости Азербайджана», Торунь, 9-11 мая 2018 г.

\footnotetext{
A sia is a continent which has few countries that influence the rest of the world in many various aspects. For example, China does it economically, Russia has political and military influence while Japan fascinates people with its culture. All of that and much more make Asia a place of unquestionable meaning and necessary to be understood, especially by people interested in international affairs and global politics. A great opportunity for such people is International Asian Congress organized annually by Adam Marszalek Press in Toruń, Poland. This years' edition was focused on the topic of Azerbaijan and Poland's independence, however the core of the event was, as in previous years, Asia itself.

The Congress is a huge event thus its biggest downside is that it is simply not possible to attend all panels and presentations. I had a pleasure of
} 
attending the panel entitled Religion and health service in Asia: problems and perspectives.

It was started by a presentation which I have prepared with Kamila Rezmer, the Congress secretary, and Cristina Ghenu, a collaborator from Romania. The speech aimed to grasp biopolitics in the frames of risk management and to present what kinds of approaches to security matters are possible through such an operation. We focused mainly on macro-scale matters such as domestic violence policy, migrations and biopolitical discourses of communities. The most important matter, however, was a problem of overpopulation to which we paid special attention by discussing it in the light of anti-natalist theories. We still claim that this is the most serious biopolitical challenge today, not only for Asia but for the whole world.

The panel has been continued by Malwina Krajewska from Nicolaus Copernicus University in Toruń, who gave a speech about Tibetan Monasticism in Exile. It is necessary to mention that monasticism is fundamental to both Mahayana and Theravada Buddhist philosophies. It is no wonder that Tibet is no exception and also had a monastic establishment consistent with Buddhist norms. This is why the author took a sociological approach and presented them in the wider social context of monasticism withdrawal.

Mangal Kanti Chakma took a way different approach than the previous speaker and was speaking about the Doctrine of Buddhist Psychology with the special emphasis put on phenomenology. Through the number of references to the classical terms of this field, he demonstrated the differences between them and their Buddhist equivalents. They assume that the most known references to Jungian psychologism or a general Buddhist idealism are mistaken because the center of Yogācāra is not only consciousness or mind. The Buddhist phenomenology is a bit wider and depends on the happy realization and affirmation of consciousness to achieve full cognition.

Another presentation was prepared by Mahammad Amrahov who was speaking about bioethics in the Buddhist culture. The author's approach to bioethics was very focused because the emphasis was put on the medical ethics. As such, the topic comprised the general rules and assumptions of medical service behavior in native cultures and multicultural incidents. The interesting mention was that practicing medicine in some Asian sub- 
-cultures is in hand of the people which makes bioethics there more case-based and less due to the state rules.

Banani Chakma gave a speech about the contributions of the International Centre for Diarrhoeal Disease Research in Bangladesh (ICDDRB). The presenter took institutional and functional approach in order to demonstrate the organization's place and achievements in the country. The institution is one of the leading research institutes in Bangladesh. It has international staff including scientists from many different disciplines, focused on the fight against infectious diseases. Beside conducting a lot of research, members of the organization are activists who contribute in lifesaving operations, e.g. post-tsunami health support in Sri Lanka, 2005.

The next speaker, Kallol Chakma discussed "The ups and downs of the Buddhism" in Asia. The most interesting author's observation was that Buddhism, which is associated with values such as peace, love, nirvana, clear mind and so on, was not always a peaceful religion. As many others, also Buddhism had a dark moments in its history and in radical version led to bloodshed and ideological indoctrination. I think that we need more presentations like that to remember that any kind of fanaticism is dangerous, independently of the place and time.

The panel was closed by Suvaddra Chakma who presented "The relationship between the Buddhism and the Chakma community usually in the south Asia". This religion is especially important for these people because they have been practicing it for many centuries. Even today almost every Chakma (or Changma) village is Buddhist and oriented around monastery life, monks and spiritual life. Because of the strong connection between the people and religion, Chakmas have a lot of characteristic festivals including Bizu, Alphaloni, Buddha Purnima and Kathin Civar Dan.

Attending the panel definitely was a great cultural and scientific experience. I hope that the Congress organizers will prepare a similar panel in the next editions of the event. It greatly enriched the $\mathrm{V}^{\text {th }}$ Congress and I think that all of its participants can count on the same next years. 
BARTOSZ PŁOTKA, MA

Faculty of Political Science and International Studies

Nicolaus Copernicus University

Batorego 39 L, 87-100 Toruń

bplotka.umk@gmail.com 